\title{
Pengaruh Penggunaan IFS terhadap Kinerja dan Kreativitas Karyawan PT PAL Indonesia (Persero) dengan Pendekatan Task-Technology Fit (TTF) dan Technology Acceptance Model (TAM)
}

\author{
Evita Dhany, Syarifa Hanoum, dan Muniroh Soemarsono \\ Departemen Manajemen Bisnis, Institut Teknologi Sepuluh Nopember (ITS) \\ e-mail: munirohsoemarsono@gmail.com
}

\begin{abstract}
Abstrak-Penggunaan teknologi yang semakin canggih memberikan dampak yang positif bagi banyak perusahaan. Hal ini juga mendorong perusahaan untuk menggunakan teknologi di dalam segala aktivitas bisnisnya. Sebagai contoh penggunaan sistem informasi IFS di PT PAL Indonesia (Persero). Perusahaan yang besar memerlukan sistem informasi berupa ERP untuk dapat membantu menyelesaikan pekerjaan karyawan. Sistem informasi yang dimaksud adalah IFS. Beberapa penelitian terdahulu telah menganalisis penggunaan sistem informasi dengan beberapa pendekatan model TAM, TTF, UTAUT dan beberapa model yang lainnya dan telah dijadikan acuan untuk penelitian ini. Tujuan penelitian ini adalah menganalisis pengaruh penggunaan IFS yang diterapkan di PT PAL Indonesia (Persero) mengenai kinerja karyawan dengan pendekatan Task Technology Fit (TTF) dan Technology Acceptance Model (TAM). Selain itu tujuan yang kedua adalah menganalisis pengaruh kinerja terhadap kreativitas karyawan PT PAL Indonesia (Persero). Jenis penelitian yang digunakan adalah conclusive descriptive dan survey dan menggunakan SEM PLS untuk menguji hipotesis yang dibuat dalam penelitian ini. Pengumpulan data dilakukan dengan menyebarkan lembaran kuisioner kepada 320 karyawan pengguna IFS di PT PAL Indonesia (Persero). Hasil penelitian menunjukkan adanya 9 hipotesis yang berhubungan signifikan. Sedangkan, terdapat 2 hipotesis yang berhubungan negatif antar variabel. Dari hasil 2 hipotesis yang bertolak belakang perlu dilakukan evaluasi dan perbaikan dari penggunaan IFS sehingga dapat menghasilkan kinerja dan kreativitas karyawan yang lebih baik lagi. Selain itu, perlu meningkatkan pengetahuan mengenai penggunaan IFS dan perlu adanya pelatihan penggunaan IFS dan mmbagikan manfaat menggunakan sistem informasi IFS dalam bekerja karena akan meningkatkan kinerja dan kreativitas karyawan PT PAL Indonesia (Persero).
\end{abstract}

Kata Kunci-IFS, Kinerja, Kreativitas, TAM, TTF

\section{PENDAHULUAN}

$\mathrm{P}$ ERKEMBANGAN harus menyesuaikan diri dengan kondisi yang ada. Penyesuaian teknologi yang semakin canggih saat ini mendorong perusahaan untuk menyesuaikan diri dalam persaingan yang ketat. Perusahaan diri yang dilakukan adalah melibatkan kecanggihan teknologi dalam setiap lini usahanya. Menurut Dityawarman et al (2016) perusahaan saat ini dituntut untuk berkembang dengan memperbarui penggunaan teknologi informasi beserta sistem operasinya. Faktor lain juga disebabkan dari lingkungan yang semakin kompetitif membuat perusahaan bergantung pada kinerja teknologi. Teknologi informasi memiliki peran dalam mengolah data menjadi suatu informasi. Sumber Daya Manusia menjadi pengolah data yang menghasilkan suatu informasi [1]. Terbukti bahwa era informasi yang sedang berkembang untuk dapat mencapai tujuannya perlu menggunakan sistem informasi yang canggih sehingga dapat membantu pengolahan data yang dimiliki. Seperti penelitian terdahulu yang dilakukan oleh Cheng (2018) menjelaskan salah satu sistem informasi perusahaan yang digunakan untuk mendukung segala kegiatan organisasi adalah Enterprise Resource Planning (ERP). Enterprise Resource Planning (ERP) merupakan paket software aplikasi yang membantu organisasi untuk mengelola sumber daya yang dimiliki, membagikan informasi antar departemen dan mengintegrasikan beberapa operasional bisnis lebih kompleks dan berhubungan oleh pelanggan [2]. Perusahaan perlu menggunakan sistem informasi ERP untuk dapat mengintegrasikan data dalam memudahkan pekerjaan yang dilakukan karyawan. Sistem ERP dirancang untuk membangun server perusahaan yang memfasilitasi informasi yang terintegrasi secara lengkap sesuai proses bisnis yang dilakukan seluruh unit fungsional dalam suatu organisasi dan menggunakan database. Penggunaan sistem informasi ERP memiliki banyak keuntungan yang dapat dirasakan perusahaan. Keuntungan dalam menggunakan ERP adalah dapat merampingkan proses bisnis suatu organisasi dan dapat diterima baik oleh suatu organisasi [3]. Walaupun dibutuhkan biaya yang besar untuk mengadopsi penggunaan ERP tetapi memberikan keuntungan yang banyak bagi perusahaan.

PT PAL Indonesia (Persero) adalah salah satu perusahaan BUMN yang bergerak dalam industri pembuatan transportasi laut di Indonesia dengan jumlah karyawan kurang lebih 1.585 personil. PT PAL Indonesia (Persero) sebagai salah satu industri strategis yang memiliki peran besar dalam pembuatan kapal di Indonesia untuk mendukung kemajuan kondisi maritim di Indonesia. Salah satu strategi perusahaan ini dalam mengelola Sumber Daya Manusia adalah pemangkasan bisnis proses dengan membangun sistem informasi dengan penggunaan software yang disebut SAP. Software SAP (System Application and Processing) adalah salah satu jenis ERP yang dapat mengintegrasikan proses bisnis perusahaan. Penggunaan software SAP tersebut kini diganti dengan penggunaan software IFS diberlakukan semenjak tahun 2016 karena sistem informasi yang saat ini memiliki lingkup yang lebih luas dan lebih banyak kegunaan yang tidak hanya mengurus operasional tetapi dapat menginput data diri karyawan sesuai dengan kebutuhan. IFS (Industrial and Financial System) adalah sistem informasi yang digunakan perusahaan sebagai salah satu strategi untuk dapat mengontrol biaya yang digunakan proses produksi sehingga menghasilkan pendapatan yang lebih besar selain itu IFS juga digunakan untuk mengelola data, jam kerja, dan dokumen proyek perusahaan.

Permasalahan yang dihadapi perusahaan dalam menggunakan IFS yaitu hanya beberapa users yang tersedia dan keterbatasan untuk mengakses data. Users yang tersedia terbatas karena harga satu user biaya yang 
dibutuhkan sangat mahal. Selain itu menurut penggunaan fitur bahasa yang digunakan dalam sistem informasi IFS susah diterima oleh karyawan yang menggunakan. Dari keputusan penggunaan sistem informasi oleh perusahaan terdapat banyak beberapa masalah yang dihadapi. Keuntungan yang seharusnya dirasakan oleh pengguna dalam menggunakan sistem informasi IFS adalah data yang sudah diintegrasi dan bisa digunakan bagian lain walau terbatas, dan membantu mempercepat proses pengambilan keputusan.

Dari permasalahan yang terjadi, dilakukan analisis Penggunaan sistem informasi IFS apakah memberikan dampak yang positif dalam menyelesaikan pekerjaan karyawan dengan hasil dapat meningkatkan kinerja karyawan. Dalam penelitian ini, menganalisis pengaruh kinerja terhadap kreativitas karyawan dimana dalam konteks penggunaan sistem informasi IFS kreativitas karyawan dalam memengaruhi pengambilan keputusan. Analisis penggunaan sistem informasi IFS dilakukan melalui pendekatan bagaimana teknologi bisa menyelesaikan pekerjaan karyawan dan kemudahan yang dirasakan karyawan. Perbedaan penelitian ini dengan penelitian sebelumnya adalah mengacu pada sampel yang lebih spesifik yaitu karyawan PT PAL Indonesia (Persero) dengan pendekatan model penelitian kombinasi dari penelitian sebelumnya yaitu Task Technology Fit (TTF) dan Technology Acceptance Model (TAM).

Penelitian ini mengangkat studi kasus PT PAL Indonesia (Persero) sebagai salah satu perusahaan yang mendukung poros maritim di Indonesia. Sebagai negara berkembang Indonesia merupakan negara maritim terbesar dalam peringkat kelima di dunia dengan luas wilayah laut sebesar 3,2257,483 $\mathrm{Km}^{2}$. Dengan mengangkat studi kasus perusahaan PT PAL Indonesia dapat menjadikan negara Indonesia sebagai negara yang lebih maju dalam bidang maritim. Selain itu untuk mengikuti perkembangan dalam kelas dunia, perusahaan ini bekerja sama dengan mendukung arah pengembangan rekayasa umum yang diarakhkan pada pemeliharaan dan pengembangan sebagai pemasok sumber daya untuk perusahaan pembangkit listrik besar di dunia. Untuk mewujudkan hal ini, PT PAL Indonesia (Persero) bekerja sama dengan perusahaan shipbuilding yang berada dalam sepuluh besar di dunis yaitu Mitsubishi Heavy Industri yang berada dalam peringkat lima di seluruh dunia (statistics, 2016). dalam bidang merancang bangunan boiler untuk pembangkit tenaga listrik. Selain itu PT PAL Indonesia (Persero) merupakan perusahaan pendukung kapal angka. Pada Tahun 2016 PT PAL Indonesia (Persero) merupakan peringkat satu yang berhasil memenangkan Sistem Manajemen Keselamatan dan Kesehatan Kerja (SMK3) Ministry of Civil Work.

\section{LANDASAN TEORI}

\section{A. Kinerja dan Kreativitas}

Menurut Sedarmayanti kinerja karyawan adalah hasil kerja secara kuantitas dan kualitas yang dicapai oleh seorang karyawan dalam melaksanakan tugas dan tanggung jawabnya [4]. Karyawan yang memiliki kinerja yang baik akan berdampak besar terhadap kinerja perusahaan. Kinerja karyawan yang baik ditandai dengan kemampuan karyawan menyelesaikan tugas tepat waktu dan dapat mencapai setiap target yang telah ditetapkan oleh perusahaan. Hal tersebut memiliki persamaan dengan pengertian kinerja sebagai sistem yang digunakan untuk menilai dan mengetahui apakah seseorang karyawan telah melaksanakan pekerjaannya secara keseluruhan atau sebagai perpaduan dari hasil kerja (sesuatu yang harus dicapai seseorang) dan kompetensi (bagaimana cara mencapainya) [4].

Kreativitas muncul dari produksi novel dan ide-ide berguna oleh individu atau sekelompok individu yang bekerja bersama . Agar kreativitas terjadi dalam organisasi, manajer perlu mendukung dan mempromosikannya, karena mereka adalah individu yang paling berpengetahuan tentang hasil kerja karyawan yang harus kreatif dan mereka memiliki pengaruh yang besar terhadap konteks di mana kreativitas dapat terjadi [5]. Informasi sangat mendukung proses kreativitas karyawan dalam bekerja. Informasi yang diterima dan mudah diakses akan memberikan kreatifitas yang tinggi bagi karyawan [6]. Karakteristik pekerjaan juga merupakan salah satu kontributor bagi munculnya kreativitas karyawan [7]. Pekerjaan yang dikerjakan dengan antusiasme yang tinggi akan menumbuhkan kreativitas dalam bekerja [8]. Dengan adanya sistem pendukung kreativitas biasanya karyawan akan memiliki banyak ide untuk mengambil keputusan yang cepat dalam pekerjaannya. Penelitian Amabile (1996) menjadikan Creativity Support Systems dirancang secara khusus untuk memberikan isyarat yang dapat meningkatkan kinerja kreatif individu dan kelancaran ide dianggap sebagai aspek dari kinerja yang kreatif.

\section{B. Model Penelitian}

Model penelitian merupakan suatu kerangka dari pelaksanaan penelitian yang berisi variabel yang digunakan untuk mengetahui suatu hasil penelitian. Model pada penelitian ini mengacu pada dua literatur penelitian terdahulu Chung et al (2014) dan Elmorshidy (2018). Penelitian ini mencoba untuk menganalisis masalah pengaruh penggunaan penggunaan IFS (Industrial and Financial System) di PT PAL Indonesia (Persero) terhadap kinerja dan kreativitas dengan melakukan kombinasi model dari penelitian terdahulu yang sudah dilakukan yaitu dengan pendekatan model Task Technology Fit (TTF) dan Technology Acceptance Model (TAM). Penelitian ini menggunakan pendekatan model Task Technology Fit (TTF) karena dirasa model ini merupakan penugasan pekerjaan dengan menggunakan sistem teknologi.

Model Task-Technology Fit (TTF) didefinisikan sebagai sejauh mana Teknologi membantu seseorang dalam melakukan portofolio tugasnya [9]. Technology Acceptance Model (TAM) pada awalnya diusulkan oleh [10]. TAM adalah teori sistem informasi dalam bentuk kerangka model yang menunjukkan bagaimana pengguna teknologi datang untuk menerima dan menggunakannya. Menurut Davis (1989), dan Venkatesh (2003), niat perilaku untuk menggunakan teknologi muncul ketika individu merasa bahwa teknologi akan berguna dan mudah untuk menggunakan teknologi yang diperlukan. Karyawan PT PAL Indonesia (Persero) dituntut untuk dapat menggunakan sistem informasi yang tersedia demi kelancaran proses bisnis. Setelah itu, penggunaan teknologi informasi ini perlu dievaluasi apakah dapat diterima oleh karyawan sehingga model penelitian dimodifikasi dengan pendekatan model Technology Acceptance Model (TAM). 


\section{1)Pengaruh Perceived Job Performance terhadap dengan \\ Perceived Job Creativity}

Dalam melakukan suatu pekerjaan kreatifitas didefinisikan sebagai suatu penciptaan yang berharga, produk baru yang berguna, pelayanan, ide, prosedur atau proses yang dikerjakan karyawan bersama-sama dalam suatu sistem kerja [11]. Sedangkan, kinerja merupakan hasil kerja atau pencapaian dari pekerjaan yang sudah dilakukan [12]. Menurut penelitian X. Zhang and K. M. Bartol adanya hubungan positif antara keterlibatan proses kreatifitas terhadap kinerja pekerjaan secara keseluruhan [13]. Oleh karena itu, pada penelitian ini memiliki hipotesis:

$\mathbf{H}_{1}$. Perceived job performance memiliki hubungan yang positif terhadap perceived job creativity dalam penggunaan sistem informasi IFS di PT PAL Indonesia (Persero).

2)Pengaruh Behavioral Intention to Use IFS terhadap

Perceived Job Performance.

Behavioral Intention adalah perilaku intens seseorang dalam menggunakan sistem teknologi yang tersedia. Perilaku intens penggunaan sistem informasi IFS diharapkan dapat memberikan dampak positif bagi kinerja karyawan. Model yang tersedia memprediksi seseorang yang memiliki perilaku intens dalam penggunaan IFS diprediksi akan mempengaruhi kinerja karyawan PT PAL Indonesia Persero.

H2. Behavioral intention to use IFS memiliki pengaruh yang positif terhadap perceived job performance.

3) Pengaruh Perceived Usefulness of IFS dan Attitude

towards Using IFS terhadap Behavioral Intention to Use IFS

Behavioral Intention to use merupakan kecenderungan perilaku seseorang untuk menggunakan teknologi. Tingkat seseorang dalam menerima penggunaan teknologi dapat diprediksi dari sikap perhatiannya dalam menggunakan teknologi tersebut. Model yang diterapkan TAM memprediksi ketika seseorang yang memiliki persepsi kegunaan teknologi akan cenderung menggunakan teknologi tersebut. Ketika seseorang menunjukkan sikapnya dalam menggunakan teknologi mempengaruhi perhatiannya untuk menggunakan suatu sistem teknologi. Dari beberapa prediksi yang dijelaskan maka dihasilkan suatu hipotesis yaitu:

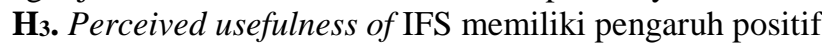
terhadap behavioral intention to use IFS.

H4. Attitude towards using IFS memiliki pengaruh positif terhadap behavioral intention to use IFS.

4) Pengaruh Perceived Ease of Use of IFS dan Perceived

Usefulness of IFS terhadap Attitude towards Using IFS

Menurut Davids attitude towards using adalah sikap seseorang dalam menggunakan sistem teknologi teknologi [11]. Sistem tersebut dapat berupa penerimaan atau penolakan sebagai dampak dari penggunaan sistem teknologi dalam suatu pekerjaan. Sikap yang timbul dapat dilihat setelah sesorang menggunakan teknologi dalam pekerjannya. Disaat seseorang merasakan kemudahan dalam menggunakan teknologi diduga akan mempengaruhi sikap seseorang menggunakan sistem teknologi. Begitu juga ketika orang merasakan kegunaan menggunakan sistem teknologi diduga akan mempengaruhi sikap dalam menggunakan sistem teknologi tersebut. Oleh karena itu dari ketiga variabel di atas dihasilkan suatu hipotesis yaitu:

H5. Perceived usefulness of IFS memiliki pengaruh positif terhadap Attitude towards using IFS.

H6. Perceived ease of use of IFS memiliki pengaruh yang positif terhadap Attitude towards using IFS.

\section{5) Pengaruh Perceived Ease of Use of IFS terhadap} Perceived Usefulness of IFS

Dalam Technology Acceptance Model (TAM) memiliki dua variabel dasar yang berhubungan. Dua variabel tersebut adalah Perceived ease of use dan perceived usefulness. Perceived ease of use merupakan persepsi kemudahan dalam penggunaan teknologi sedangkan perceived usefulness merupakan persepsi kegunaan teknologi. Kedua variabel di atas diduga saling mempengaruhi karena ketika seseorang merasakan kemudahan dalam menggunakan teknologi sehingga orang tersebut dapat merasakan manfaat teknologi yang digunakannya. Dari kedua variabel tersebut maka dihasilkan suatu hipotesis yaitu:

$\mathbf{H}_{7}$. Perceived ease of use of IFS memiliki dampak yang positif terhadap perceived usefulness of IFS.

6) Pengaruh TTF terhadap Perceived Usefulness of IFS dan Perceived Ease of Use of IFS

Model TTF berpendapat bahwa Teknologi Informasi (TI) bermanfaat untuk kinerja individu, jika TI digunakan dan fungsi yang disediakan oleh TI sesuai dengan tugas individu [14]. Model teoritis TTF telah diperluas dengan model penerimaan penggunaan teknologi informasi [15]. Maka dari itu model TTF sangat cocok untuk dimodifikasi dengan model TAM. Perceived usefulness dan perceived ease of use merupakan variabel dasar yang dimiliki oleh model TAM. Menurut Davis Perceived usefulness merupakan persepsi seseorang menganggap penggunaan teknologi informasi akan meningkatkan kinerjanya [16]. Perceived ease of use adalah persepsi seseorang dengan mudah menggunakan sistem teknologi. Ada beberapa hipotesis dalam sub bab ini yang merupakan variabel yang mempengaruhi kinerja karyawan, hipotesis tersebut adalah:

H8a. TTF berpengaruh positif terhadap perceived ease of use dalam penggunaan IFS.

Hsb. TTF berpengaruh positif terhadap perceived usefulness dalam penggunaan IFS.

7) Pengaruh Task Related Factors terhadap TTF

Pada dasarnya, penggunaan teknologi akan bersepsi bahwa teknologi yang mereka gunakan cocok ketika tugas yang mereka kerjakan dapat difasilitasi dengan menggunakan sistem teknologi yang tersedia [17]. Dalam penelitian Chung variabel task related factors adalah respon dan perilaku yang seharusnya ditunjukan oleh performer [15].

H9. Task related factors berhubungan positif dengan TTF dalam konteks penggunaan IFS.

\section{8) Pengaruh dari Technology Characteristics terhadap} TTF

Model asli TTF yang dibuat oleh Goodhue dan Thompson [17] dalam situasi tertentu dimana pengguna teknologi mengukur karakteristik sistem dalam konteks yang sama. Dalam penelitian Chung et al merelasikan TTF dengan konteks penggunaan aplikasi Enterprise Mobile Application (EMA) terdiri dari reliabilitas, aksesbilitas, dan keseluruhan kualitas dari aplikasi EMA itu sendiri [15]. Technology characteristics merupakan karakteristik teknologi sehingga penggunaan sistem teknologi memiliki keuntungan yang besar [18].

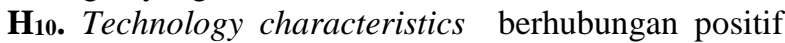
dengan TTF dalam konteks penggunaan IFS. 


\section{METODOLOGI}

Penelitian ini memiliki empat tahapan penelitian. Tahapan yang pertama adalah tahapan pendahuluan. Tahapan pendahuluan merupakan tahapan utama yang berisi permasalahan penelitian dan studi literatur. Tahapan yang kedua adalah tahapan spesifikasi model yaitu tahapan yang menjelaskan model penelitian, hipotesis, dan definisi dari variabel yang digunakan. Tahapan yang ketiga adalah tahapan pengumpulan data terdiri dari objek penelitian, jenis penelitian, populasi dan teknik sampling, jenis data yang dibutuhkan, dan pengumpulan data. Sedangkan tahapan yang terakhir adalah tahapan pengolahan data dari data yang sudah terkumpul dan dilakukan analisis terhadap data tersebut. Dengan 11 hipotesis penelitian, penelitian ini diolah dengan menggunakan PLS SEM (Partially Least Square Structural Equation Model). Sebelum mengolah data secara keseluruhan dilakukan pilot test yang berguna untuk menguji pertanyaan yang terdapat dalam kuisioner dapat dinyatakan valid dan reliabel. Data yang dibutuhkan dalam pilot test sebanyak 30 responden. Apabila nilai validiyas dan reliabilitas sesuai dengan standar yang ada tahapan pengumpulan data dapat dilanjutkan. Dengan jenis penelitian conclusive descriptive dan survey. Penelitian ini menyebarkan lembaran kuisioner dengan teknik populasi. Populasi yang didapatkan adalah sebanyak 320 responden. Karyawan yang dituju adalah karyawan tetap dan tidak tetap PT PAL Indonesia (Persero) yang menggunakan sistem informasi IFS dalam bekerja.

\section{ANALISIS DAN DISKUSI}

\section{A. Analisis Demografi}

Berdasarkan data dari 320 responden yaitu karyawan PT PAL Indonesia (Persero) menghasilkan demografi yang berbeda-beda. Demografi terdiri dari usia, jenis kelamin, pendidikan terakhir, lama bekerja, lama menggunakan IFS, dan jabatan. Berikut merupakan penjelasan presentase dan frekuansi masing-masing demografi responden. Penjelasan demografi yang pertama adalah berdasarkan usia. Berdasarkan data yang diperoleh memaparkan usia responden yang berjumlah 320 karyawan PT PAL Indonesia (Persero). Usia dibagi menjadi lima kelompok, yaitu usia 2025 Tahun sejumlah $79(24,7 \%)$, usia 26-30 Tahun sejumlah 73 (22,8\%), usia 31-35 Tahun sejumlah 45 (14,1\%), usia 3640 Tahun sejumlah $28(8,8 \%)$, dan responden dengan usia $>40$ Tahun sejumlah 95 (29,7\%). Dapat disimpulkan, karyawan PT PAL Indonesia (Persero) yang menjadi responden dalam penelitian ini dominan karyawan yang berusia $>40$ Tahun. Pada usia ini banyak karyawan senior yang bekerja di perusahaan karena PT PAL Indonesia (Persero) merupakan perusahan Badan Usaha Milik Negara yang sudah cukup lama berdiri. Selain itu karyawan yang berusia $>40$ Tahun adalah biasanya karyawan yang lebih lama menggunakan IFS karena dianggap lebih dulu menggunakan IFS.

Tabel 1 menjelaskan demografi jenis kelamin responden. Dari 320 karyawan, responden berjenis kelamin Laki-laki sejumlah $188(58,8 \%)$ dan sejumlah $132(41,3 \%)$ berjenis kelamin perempuan. Hasil tersebut menandakan bahwa jumlah responden yang mengisi kuisioner sebagian besar adalah Laki-laki. Jika dilihat dari jumlah karyawan secara keseluruhan jumlah karyawan laki-laki lebih banyak dibandingkan dengan perempuan. Hal tersebut dikarenakan
PT PAL Indonesia (Persero) merupakan perusahaan

Tabel 1.

Demografi Responden

\begin{tabular}{|c|c|c|}
\hline 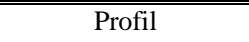 & Frekuensi & Presentase (\%) \\
\hline \multicolumn{3}{|l|}{ Usia } \\
\hline 20-25 Tahun & 79 & 24,7 \\
\hline 26-30 Tahun & 73 & 22,8 \\
\hline 31-35 Tahun & 45 & 14,1 \\
\hline 36-40 Tahun & 28 & 8,8 \\
\hline$>40$ Tahun & 95 & 29,7 \\
\hline \multicolumn{3}{|l|}{ Jenis Kelamin } \\
\hline Laki-laki & 188 & 58,8 \\
\hline Perempuan & 132 & 41,3 \\
\hline Total & 320 & 100,0 \\
\hline \multicolumn{3}{|l|}{ Pendidikan Terakhir } \\
\hline SMA/SMK & 68 & 21,3 \\
\hline D3/D4 & 51 & 15,9 \\
\hline S1 & 177 & 55,3 \\
\hline S2 & 21 & 6,6 \\
\hline Lain-lain & 3 & 0,9 \\
\hline \multicolumn{3}{|l|}{ Lama Bekerja } \\
\hline 1-5 Tahun & 145 & 45,3 \\
\hline 6-10 Tahun & 46 & 14,4 \\
\hline 11-15 Tahun & 19 & 5,9 \\
\hline 16-20 Tahun & 21 & 6,6 \\
\hline$>20$ Tahun & 89 & 27,8 \\
\hline \multicolumn{3}{|l|}{$\begin{array}{l}\text { Lama Menggunakan } \\
\text { IFS }\end{array}$} \\
\hline 1-3 Bulan & 56 & 17,5 \\
\hline 4-6 Bulan & 63 & 19,7 \\
\hline 1 Tahun & 100 & 31,3 \\
\hline 2 Tahun & 33 & 10,3 \\
\hline 3 Tahun & 68 & 21,3 \\
\hline \multicolumn{3}{|l|}{ Jabatan } \\
\hline Kepala Divisi & 4 & 1,3 \\
\hline Kepala Departemen & 4 & 1,3 \\
\hline Kepala Biro & 47 & 14,7 \\
\hline Sekretaris Divisi & 13 & 4,1 \\
\hline Staff & 252 & 78,8 \\
\hline Total & 320 & 100,0 \\
\hline
\end{tabular}

pembuatan kapal dan galangan dimana biasanya pekerjaan tersebut atau bidang tersebut lebih banyak dilakukan oleh laki-laki. Pekerjaan berhubungan dengan bahan-bahan yang berat terutama dalam proses pembuatannya langsung sehingga lebih cocok dilakukan oleh laki-laki. Selain itu pekerjaan yang berada di langsung di lapangan berbahaya bagi perempuan karena berhubungan dengan benda-benda yang memiliki volume yang berat sehingga pekerjaan lapangan banyak dilakukan oleh laki-laki.

Terdapat lima kategori Pendidikan terakhir dalam kuisioner penelitian ini. Kategori pertama adalah responden dengan pendidikan terakhir SMA atau SMK yaitu sejumlah $68(21,3 \%)$. Untuk kategori pedidikan terakhir Diploma (D3/D4) sejumlah 51 (15,9\%), untuk responden dengan pendidikan terakhir Sarjana (S1) sejumlah 177 (55,3\%) dan Magister (S2) sejumlah 21 
$(6,6 \%)$. Dan responden yang lain dengan pendidikan terakhir dan lain-lain seperti D2, D1, atau yang lain berjumlah 3 $(0,9 \%)$. Oleh karena itu, dapat disimpulkan mayoritas responden yang berpartisipasi dalam penelitian ini adalah responden dengan pendidikan terakhir sarjana (S1). PT PAL Indonesia (Persero) saat ini lebih banyak memberikan kesempatan kepada pelamar yang lulus dengan gelar sarjana karena lebih memiliki pengalaman dan pengetahuan yang lebih kompleks dan proses belajar yang lebih lama sehingga dalam praktiknya perusahaan saat ini lebih banyak merekrut calon pekerja dengan pendidikan terakhir Sarjana atau yang lebih tinggi.

Pada demografi lama bekerja terdiri dari lima kategori lama waktu bekerja di PT PAL Indonesia (Persero). Pertama, bekerja di perusahaan selama 1-5 tahun sejumlah 145 orang $(45,3 \%)$. Kedua, karyawan yang bekerja di perusahaan ini selama 6-10 tahun sejumlah 46 orang $(14,4 \%)$. Selanjutnya, untuk lama bekerja selama 11-15 t

tahun terdapat 19 orang $(5,9 \%)$, lama bekerja selama 16 20 tahun terdapat 21 orang $(6,6 \%)$ dan karyawan yang bekerja di perusahaan selama $>20$ Tahun sebesar 89 orang $(27,8 \%)$. Dapat disimpulkan mayoritas responden adalah karyawan yang bekerja di PT PAL Indonesia (Persero) dengan pengalaman kerja selama 1-5 Tahun. Dimana waktuwaktu tersebut adalah dimana banyak karyawan yang baru bergabung dengan PT PAL Indonesia (Persero). Sehingga dapat dikatakan mayoritas responden adalah karyawan baru. Sama dengan demografi yang sebelumnya, demografi lama penggunaan IFS dibagi dengan lima kategori. Kategori pertama adalah karyawan yang menggunakan IFS selama 13 Bulan yaitu berjumlah 56 orang $(17,5 \%)$. Kategori kedua adalah karyawan yang menggunakan IFS selama 4-6 Bulan yaitu berjumlah 63 orang $(19,7 \%)$. Kategori yang ketiga adalah karyawan yang menggunakan IFS sudah 1 Tahun sebanyak 100 orang $(31,3 \%)$. Selanjutnya kategori karyawan yang menggunakan IFSselama 2 Tahun sebanyak 33 orang (10,3\%). Terakhir, adalah kategori karyawan yang menggunakan IFS selama 3 Tahun yaitu sejumlah 68 orang $(21,3 \%)$. Dapat dilihat berdasarkan presentase lama penggunaan IFS, karyawan yang menjadi responden adalah karyawan yang menggunakan IFS selama 1 Tahun. Karyawan yang menggunakan IFS sudah selama 1 Tahun tergolong karyawan yang baru aktif dalam menyelesaikan tugasnya menggunakan IFS karena IFS digunakan di perusahaan sejak tahun 2016.

Pada Tabel 1 jabatan karyawan yang tertera dalam kuisioner adalah kepala divisi, kepala departemen, kepala divisi, sekretaris divisi, dan staf. Responden yang berada pada posisi kepala divisi sebanyak 4 orang $(1,3 \%)$, kepala departemen sebanyak 4 orang $(1,3 \%)$, kepala biro sebanyak 47 orang $(14,7 \%)$, sekretaris divisi sebanyak 13 orang $(4,1 \%)$, dan staff sebanyak $252(78,8 \%)$. Oleh karena itu dapat diambil kesimpulan bahwa mayoritas responden adalah karyawan yang bekerja sebagai staff karena jumlah karyawan yang bekerja sebagai staff di PT PAL Indonesia (Persero) terdiri dalam jumlah yang banyak. Selain itu banyak staff yang menggunakan IFS dalam menyelesaikan pekerjaannya berbeda dengan jabatan top management atau middle management tidak banyak yang menggunakan IFS karena bergantung dengan tugas dan tanggung jawabnya masingmasing sehingga tidak menggunakan IFS secara langsung.

\section{B. Uji Asumsi Klasik}

\section{1) Missing Values}

Missing values atau data yang kurang lengkap dapat menyebabkan error atau permasalahan dalam pengolahan data. Hal tersebut dikarenakan software yang digunakan tidak dapat mengolah data yang ada. Untuk menghindari hal tersebut, dilakukan dengan pengecekan kembali terhadap jawaban responden yang ada. Jika terdapat jawaban yang tidak lengkap perlu dilakukan penghapusan responden dalam pengolahan data. Dari 320 kuisioner yang disebarkan, tidak ditemukan missing values. Seluruh responden telah mengisi kuisioner dengan lengkap tanpa ada satu pertanyaan dari kuisioner yang tidak diisi. Sehingga dapat melanjutkan ke tahapan yang berikutnya yaitu uji outlier.

\section{2) Uji Outlier}

Menurut Malhotra et al (2017) untuk melakukan uji outliers dengan melihat nilai z-score untuk dijadikan standar dapat dikatakan outlier atau tidak. Untuk menghasilkan data yang dikatakan outlier data tersebut harus memiliki nilai z-score bernilai \pm 4 . Dari 320 data yang diuji, tidak ditemukan nilai z-score yang diluar batas yang sudah ditentukan. Sehingga tidak diperlukan penghapusan data untuk menghindari kesalahan saat uji selanjutnya. Hasil yang diperoleh menunjukkan z-score terbesar yang didapatkan karyawan adalah 1,92647 dan yang terkecil adalah $-3,79819$.

3) Uji Normalitas

Uji normalitas dilakukan dengan tujuan untuk mengdientifikasi data penelitian apakah memiliki hasil dengan terdistribusi normal. Dalam melakukan penggambaran grafik Q-Q plot menunjukkan bahwa variabel penelitian yang berada disekitar garis normal memberikan arti bahwa data tersebut berdistirbusi normal. Selain melalui Q-Q plot hasil uji normalitas dapat dilihat dari nilai skewness dan kurtosis secara keseluruhan. Apabila nilai skewness berada pada rentang nilai -2 hingga +2 dan nilai kurtosis tidak lebih dari 3 sehingga data penelitian dapat dikatakan terdistribusi normal. Hasil responden, rentang nilai skewness berada pada rentang -2 hingga +2 dan nilai kurtosis tidak ada yang lebih dari 3. ). Keadaan tersebut menyimpulkan bahwa data penelitian berdistribusi normal. Selain itu uji normalitas juga dapat dilakukan dengan melihat grafik Q-Q plot dan grafik menunjukkan semua variabel memiliki data yang berdistribusi normal karena berada disektitar garis normal.

\section{4) Uji Linearitas}

Selanjutnya uji linearitas yang bertujuan untuk menguji hubungan antar variabel penelitian yang berada pada satu garis lurus atau linear. Untuk melakukan uji linearitas digunakan scatter plot. Berdasarkan gambar scatter plot yang memiliki arah titik (dot) pada grafik menuju ke arah kanan atas dapat disimpulkan bahwa masing-masing variabel memiliki hubungan yang lurus atau linear.

\section{5) Implikasi Manajerial}

Untuk implikasi manajerial pada hipotesis yang tidak berhubungan positif langkah yang perlu diambil adalah perusahaan untuk dapat menambah manfaat yang dapat dirasakan karyawan adalah membagikan keuntungan dan kegunaan menggunakan IFS. Praktisi atau divisi yang berkaitan langsung dengan teknologi dapat membagikan 
keuntungan apa saja yang dirasakan pengguna sebelum dan sesudah menggunakan IFS. Dari usaha tersebut responden yang belum merasakan pengalaman menggunakan IFS memiliki minat untuk menggunakan IFS. Oleh karena itu pengenalan kegunaan IFS yang lebih spesifik dapat dibagikan kepada karyawan.

Selain itu pada Untuk dapat meningkatkan persepsi kemudahan responden dalam menggunakan IFS perlu adanya tindak lanjut dari perusahaan. Tindak lanjut tersebut berupa adanya pelatihan dalam menggunakan sistem informasi IFS. Pelatihan dapat dilakukan secara bergantian dan pelatihan yang diberikan sesuai dengan kebutuhan masing-masing karyawan dalam menggunakan IFS. Dalam pelatihan tersebut, praktisi perlu menambahkan keuntungan dan menjelaskan pentingnya perusahaan menerapkan IFS sehingga fasilitas yang ada dapat digunakan karyawan dengan baik. Jika karyawan sudah merasa ahli atau merasa mudah menggunakan IFS dalam setiap pekerjannya karyawan akan merasakan bahwa mengunakan IFS memiliki manfaat yang banyak.

\section{KESIMPULAN/RINGKASAN}

\section{A. Kesimpulan}

Hasil analisis untuk mengetahui apakah penggunaan IFS dapat memengaruhi kinerja karyawan dengna pendekatan Technology Acceptance Model (TAM) dan Task-Technoogy Fit (TTF) dapat dilihat langsung melalui uji hipotesis yang telah dilakukan. Terdapat 10 hipotesis yang diuji sebagai jawaban untuk mengetahui penggunaan IFS terhadap kinerja karyawan. Hipotesis yang diterima berjumlah 8 yaitu $\mathrm{H}_{2}, \mathrm{H}_{4}$, $\mathrm{H}_{5}, \mathrm{H}_{6}, \mathrm{H}_{8 \mathrm{a}}, \mathrm{H}_{8 \mathrm{~b}}, \mathrm{H}_{9}, \mathrm{H}_{10}$ dan terdapat 2 hipotesis yang ditolak yaitu $\mathrm{H}_{3}$ dan $\mathrm{H}_{7}$. informasi IFS. Hasil analisis yang kedua untuk mengetahui apakah kinerja karyawan dapat memengaruhi kreativitas karyawan PT PAL Indonesia (Persero) dalam konteks penggunaan IFS. Untuk mengetahui hasil analisis dapat dilakukan dengan melihat hasil hioptesis pertama. Hasil uji hipotesis yang pertama memiliki keterangan dapat diterima. Hipotesis pertama menyatakan bahwa kinerja berhubungan positif terhadap kreativitas karyawan dengan menggunakan pendekatan TAM dan TTF. Penggunaan IFS dalam perusahaan dapat dijadikan sebagai creative system yang dapat meningkatkan kinerja dan kreativitas karyawan dalam hal kognitif. Perusahaan perlu menjadikan penggunaan IFS sebagai salah satu strategi perusahaan yang wajib diwujudkan untuk memangkas proses bisnis yang ada.

Dengan keterbatasan penelitian yang pertama adalah peneliti tidak mengetahui secara spesifik jumlah karyawan pengguna IFS. Peneliti hanya mengetahui jumlah users dan tidak mengetahui jumlah pasti karyawan yang menggunakan. Maka masalah yang dihadapi peneliti adalah perhitungan sampel berdasarkan populasi yaitu karyawan PT PAL Indonesia (Persero) padahal dalam kenyataannya belum semua karyawan menggunakan IFS. Keterbatasan yang kedua adalah peneliti tidak dapat bertatap muka secara langsung dengan masing-masing responden sehingga kurangnya informasi dan wawancara secara langsung. Keterbatasan yang ketiga adalah banyak karyawan yang pergi melakukan jalan dinas sehingga tidak mengisi kuisioner penelitian dan beberapa karyawan mengaku sibuk karena pekerjaan yang menumpuk di akhir tahun. Hal ini merupakan masalah bagi peneliti untuk menyebarkan kuisioner dalam waktu yang singkat.

\section{B. Saran}

Berdasarkan hasil penelitian yang diperoleh dan keterbatasan yang dimiliki peneliti memberikan rekomendasi untuk penelitian yang selanjutnya. Pertama, perlu adanya informasi mengenai jumlah yang spesifik yang nantinya akan menjadi responden penelitian. Kedua, perlu adanya komunikasi secara langsung dengan beberapa responden. Ketiga, menyediakan waktu yang cukup untuk dapat menyebarkan kuisioner dalam jumlah yang banyak. Keempat, melakukan penelitian lebih lanjut terhadap mengenai penggunaan IFS sebagai strategis perusahaan untuk memangkas proses bisnis dan meningkatkan kinerja karyawan.

\section{DAFTAR PUSTAKA}

[1] B. Purnawanto, Manajemen SDM Berbasis Proses. Grasindo, 2010.

[2] M. L. Nandi and A. Kumar, "Centralization and the success of ERP implementation," J. Enterp. Inf. Manag., vol. 29, no. 5, pp. 728750, 2016, doi: 10.1108/JEIM-07-2015-0058.

[3] S. Das and M. Dayal, "Exploring determinants of cloud-based enterprise resource planning (ERP) selection and adoption: A qualitative study in the Indian education sector," J. Inf. Technol. Case Appl. Res., vol. 18, no. 1, pp. 11-36, 2016, doi: 10.1080/15228053.2016.1160733.

[4] M. Sedarmayanti, Sumber Daya Manusia dan Produktivitas Kerja. Bandung: CV. Mandar Maju, 2001

[5] C. E. Shalley and L. L. Gilson, "What leaders need to know: A review of social and contextual factors that can foster or hinder creativity," Leadersh. Q., vol. 15, no. 1, pp. 33-53, 2004, doi: 10.1016/j.leaqua.2003.12.004

[6] C. E. Shalley, "Effects of Coaction, Expected Evaluation, and Goal Setting on Creativity and Productivity," Acad. Manag. J., vol. 38, no. 2, pp. 483-503, 1995, doi: 10.5465/256689.

[7] M. A. West, Innovation and creativity at work: Psychological and organizational strategies, vol. 13, no. 9. Oxford: Chichester, 1996.

[8] G. R. Oldham and A. Cummings, "Employee creativity: Personal and contextual factors at work," Acad. Manag. J., vol. 39, no. 3, pp. 607-634, 1996, doi: 10.2307/256657.

[9] D. L. Goodhue, "Task-Technology Fit and Individual Performance," Manag. Inf. Syst. Res. Cent., vol. 10, no. 3, pp. $213-$ 236, 1995, doi: 10.1093/bib/bbp020.

[10] F. D. Davis, "Perceived Usefulness, Perceived Ease of Use, and User Acceptance of Information Technology," Manag. Infromation Syst. Res. Cent., vol. 13, no. 3, pp. 319-340, 1989, doi: 10.5962/bhl.title.33621.

[11] J. Woodman, “An Introduction to Inertial Navigation,” Cambridge, 2007.

[12] H. Wibowo, Manajemen Kinerja, Jakarta: PT. 2007.

[13] X. Zhang and K. M. Bartol, "The influence of creative process engagement on employee creative performance and overall job performance: A curvilinear assessment," J. Appl. Psychol., vol. 95, no. 5, pp. 862-873, Sep. 2010, doi: 10.1037/a0020173.

[14] V. Venkatesh, M. G. Morris, G. B. Davis, and F. D. Davis, "User Acceptance of Information Technology: Toward a Unified View," MIS Q., vol. 27, no. 3, pp. 425-478, 2003, doi: 10.2307/30036540.

[15] S. Chung, K. Y. Lee, and J. Choi, "Exploring digital creativity in the workspace: The role of enterprise mobile applications on perceived job performance and creativity," Comput. Human Behav., vol. 42, pp. 93-109, 2015, doi: 10.1016/j.chb.2014.03.055.

[16] F. D. Davis, "Perceived Usefulness, Perceived Ease of Use, and User Acceptance of Information Technology," MIS Q. Manag. Inf. Syst., vol. 13, no. 3, pp. 319-339, 1989, doi: 10.2307/249008.

[17] J. Gebauer, M. J. Shaw, and M. L. Gribbins, "Task-technology fit for mobile information systems," J. Inf. Technol., vol. 25, no. 3, pp. 259-272, 2010, doi: 10.1057/jit.2010.10.

[18] barbara Wixom and P. Todd, "Understanding and Predicting Online Service Continuance : A Theoretical Integration of User Satisfaction and Technology Acceptance," Inf. Syst. Res., vol. 16, no. 1, pp. 453 466, 2005. 